\title{
ФАУНА И ФЛОРА ГОРИЗОНТАЛЬНЫХ МИКРОЭКОТОНОВ В ВОДНЫХ И НАЗЕМНЫХ ЭКОСИСТЕМАХ
}

\section{FAUNA AND FLORA HORIZONTAL MICROECONOM IN AQUATIC AND TERRESTRIAL ECOSYSTEMS}

K. Korlyakov

Summary. Microbiocenoses of soils and bottom sediments bordering on artificial substrates (curbs, concrete slabs, pillars) were studied. In the soils, an increased number of bacteria, fungi and algae was found in the marginal areas. In the bottom sediments near the edge of the silt, bacteria also dominated. The edges of the sludge was dominated by colonial forms of algae, while in the distance the brim - trichomania form. Also, crustaceans and large protozoa predominated in the marginal areas of the silt, and nematodes predominated in the distance of the edges. In the horizontal section of the soil at a distance from artificial substrates, the ecotonic geochemical effect was observed at a distance of 5-10 cm, where the concentrations of phosphates and nitrites decreased. Thus, in the marginal areas, more oxidizing conditions are formed, in addition, spores of microorganisms are washed into these areas by wind and currents, forming a kind of pool.

Keywords: bacteria, algae, soil, silt, abundance, ecotone.

\section{Введение}

$\mathbf{y}$ величение дискретности ландшафта водных и наземных экосистем в ходе внедрения искусственных сооружений ведет к трансформации органоминеральных комплексов донных отложений и почвы. Изменяется структура и динамика биогеохимических потоков, что ведет к перестройке биоценозов. Ранее на примере почв урбанизированных ландшафтов было установлено, что на стыке почв с бордюрами, бетонными плитами, фундаментами домов образуются специфические пулы микроорганизмов [7]. Кроме, того на данных стыках формируется особые химические условия почв с повышенной долей фосфатов и других окисленных соединений. Биота на этих участках представлена r-стратегами в виде водорослей и бактерий, характеризующихся более резкими вспышками численности по сравнению со схожими таксонами, обитающими в отдалении искусственных преград. В связи с чем, отдельный интерес представляют особенности распределения биоты в градиенте искусственных преград в донных отложениях водоемов. Цель настоящей работы заключалась в изучении особенностей состава
Корляков Константин Александрович

К.б.н., доцент, ФГБОУ ВО «Челябинский Государственный университет» korfish@mail.ru

Аннотация. Изучены микробиоценозы почв и донных отложений граничащие с искусственными субстратами: бордюрами, бетонными плитами, столбами. В почвах выявлена повышенная численность бактерий, грибов и водорослей на краевых участках. В донных отложениях у края илов бактерии также доминировали. С краев илов доминировали колониальные формы водорослей, тогда как в отдалении краев - трихомные формы. Также в краевых участках илов преобладали ракообразные и крупные простейшие, в отдалении краев - нематоды. В горизонтальном разрезе почвы при отдалении от искусственных субстратов экотонный геохимический эффект наблюдался на расстоянии 5-10 см, где снижались концентрации фосфатов, нитритов. Таким образом, в краевых участках формируются более окислительные условия, кроме того, в эти участки посредством ветра и течений смываются споры микроорганизмов формуя своеобразный пул.

Ключевые слова: бактерии, водоросли, почва, ил, численность, экотон.

и функционирования биоты в краевых участках и континуальном профилях почв и донных отложений, а также исследовании динамики распределения биоты при отдалении от искусственных субстратов.

\section{Материал и методы}

Для исследования были выбраны участки природных почв и урбаноземов г. Челябинска и донных отложений водоемов различной минерализации и трофической структуры. Были выбраны вертикальные преграды, искусственно разделяющие почвенный профиль, такие как бордюры (В1, В1-2; Д1, Д1-2; Е1, E1-2), бетонные (C1, C1-2; E16, Е1-2б; В1в, В1-2в) и металлические столбы (B2, В1-2). А в качестве дополнительных использовались пластиковые и минеральные (горные породы, минералы) преграды, которые вертикально погружались в почвы и донные отложения водоемов (озера Копанцево, Хомутинино, Подборное, Смолино). Каждая проба номеровалась цифрой (А, B, Д и т.д.), где дополнительная цифра 1 обозначала взятие пробы у искусственного субстрата, а цифры 1-2 взятие пробы в отдалении от преграды на расстоянии 
Таблица 1. Проективное покрытие (\%) биопленки бактерий и мицелия грибов с краевых и континуальных участков почвы.

\begin{tabular}{|c|c|c|c|}
\hline Искусственный субстрат & Группа организмов & Край & Середина \\
\hline \multirow{2}{*}{ Металлический забор } & & B2 & B2-2 \\
\hline & Бактериальная биопленка & 95 & 45 \\
\hline \multirow{3}{*}{ Тополь бальзамический } & & A1 & A1-2 \\
\hline & Мицелий & 57 & 10 \\
\hline & Бактериальная бипленка & 99 & 99 \\
\hline \multirow{3}{*}{ Бордюр } & & E1 & E1-2 \\
\hline & Мицелий & 75 & 4 \\
\hline & Бактериальная биопленка & 84 & 78 \\
\hline \multirow{3}{*}{ Бордюр } & & Д1 & Д1-2 \\
\hline & Мицелий & 87 & 15 \\
\hline & Бактериальная биопленка & 71 & 83 \\
\hline \multirow{3}{*}{ Бетонный столб } & & B1 & B1-2 \\
\hline & Мицелий & 67 & 0 \\
\hline & Бактериальная биопленка & 98 & 67 \\
\hline \multirow{2}{*}{ Бетонный столб } & & $\mathrm{C} 1$ & $C 1-2$ \\
\hline & Бактериальная биопленка & 83 & 72 \\
\hline \multirow{2}{*}{ Бетонный столб } & & B1B & $\mathrm{B} 1-2 \mathrm{~B}$ \\
\hline & Бактериальная биопленка & 45 & 29 \\
\hline \multirow{2}{*}{ Бетонный столб } & & E16 & E1-26 \\
\hline & Бактериальная биопленка & 96 & 96 \\
\hline
\end{tabular}

5-25 см. В качестве контроля один профиль вырезался около дерева (A1, A1-2). Для исследования лопатой и скребком вырезались вертикальные участки почвы высотой 15-20 см таким образом, чтобы профиль почвы, соприкасающийся с вертикальным субстратом, не нарушался и извлекался не поврежденным. Аналогичным образом для сравнения вырезался вертикальный почвенный профиль в 5-25 см от бордюров, столбов и других искусственных субстратов. Толщина почвенных профилей составляла от 1.5 до 3 см. В илах водоемов пробы вдоль искусственных субстратов брались дозатором, в песках - скребком по аналогичному методу работы с почвой. Изучение роста бактерий проводилось методом посева воды, отфильтрованной из почвы на питательный мясопептонный агар [8, 9]. Выявление количества грибов производилось путем посева на питательную среду Сабуро $[1,3,6]$. Результаты снимались в трехкратной повторности. Для изучения альгоценозов различных участков почвы на погруженный в воду профиль почвы закладывались стекла обрастания и культивировалось в течении 1.5 месяца при люминесцентном освещении и температуре воды 23 оС [4, 6, 7]. Для контрольного эксперимента изучалась численность бактерий и водорослей в илах, оцеженных из аквариума и собранных из природных водоемов (озера Хомутинино, Смолино). Пробы аналогично выборкам из природных экосистем брались с края боковой стеки контейнера и из континуальной толщи ила в отдалении краев. Концентрацию в воде $\mathrm{pH}$, соедине- ний азота и фосфора определяли методом капиллярного электрофореза на системе Капель 103-Р (ГК Люмэкс, Россия). Для статистической оценки степени связи использовали непараметрическую корреляцию Кендалла [11]. Расчеты и графические построения выполнены в пакете KyPlot и PAST [12]. Связи считали статистически достоверными при р>0,05, недостоверными - при $\mathrm{p}>0,10$.

\section{Результаты и их обсужление}

Посевы на питательную среду вытяжек из почвы и донных отложений показали более интенсивное развитие бактерий из краевых участков донных отложений и почв, что выражалось в KOE, площади проективного покрытия бактериальной биопленки и скорости роста первого и последнего показателя. Так площадь проективного покрытия биопленки лишь в 1 из 8 различных профилей почв превалировала из центра почвы (табл. 1). Тогда, как в 2 профилях были получены равные значения, и в 5 профилях площадь проективного покрытия с краю превышала таковую из середины.

Причем с края наблюдался более быстрый рост биопленки резко увеличивающийся со второго дня экспозиции. Во всех пробах из крайних участков почвы численность КОЕ росла, тогда как в середине, как правило, падала по истечении четырех дней экспозиции. В пробах А1д и А1-2д, выявлена слабая тенденция к стати- 
Таблица 2. Численность КОЕ бактерий из вытяжек ила проб, взятых вдоль искусственных субстратов и в отдалении.

\begin{tabular}{|c|c|c|c|c|}
\hline \multirow[t]{2}{*}{ Дни } & \multicolumn{2}{|c|}{$\begin{array}{l}\text { Ил из озера Смолино с пресной водой } \\
\text { (минерализация } 0.5 \text { г/л) }\end{array}$} & \multicolumn{2}{|c|}{$\begin{array}{l}\text { Ил из озера Хомутинино с соленой водой } \\
\text { (минерализация } 15 \text { г/л) }\end{array}$} \\
\hline & Край & Середина & Край & Середина \\
\hline 2 & 68 & 39 & 640 & 370 \\
\hline 3 & 365 & 143 & 688 & 441 \\
\hline 4 & 371 & 187 & 775 & 552 \\
\hline 5 & 404 & 288 & 849 & 720 \\
\hline 6 & 547 & 352 & - & - \\
\hline
\end{tabular}

стической значимости ( $\mathrm{p}=0.17)$, а в пробе В1в и В1-2в статистически достоверная связь $(p=0.04)$. Это обусловлено появлением на 3-4 сутках экспозиции в середине континуального почвенного субстрата со временем колоний грибов и объединением бактериальных колоний в биопленку. Данная тенденция отмечена также в пробах E1-2, B1, 1-2, В2-2. Аналогичная картина наблюдалась в пробах илов из искусственных условий среды (табл. 2).

На протяжении 6 дней экспозиции численность колоний бактерий проб, взятых с края ила, превалировала над численностью проб взятых из центра данных отложений. Причем более высокая численность бактерий с краю наблюдалась, как в пробах взятых из пресного озера Смолино с минерализацией 0.5 г/л, так и высокоминерализованного оз. Хомутинино с минерализацией 15 г/л. Данное более интенсивное бактериальное развитие в пробах граничащих с искусственным субстратом в водных и наземных экосистемах может объясняться аэрофильностью условий среды в трещинах и порах. Это способствует тому, что в данных пробах краевых участков доминируют аэробы, условия для развития которых и создавались в питательных средах. В связи с чем, следующим этапом было изучение состава фауны и флоры микробиоценозов представленных грибами, водорослями и животными.

Численность грибов в пробах вдоль бордюров, бетонного столба и тополя (A1, В1, Е1, Д1) с краю всегда превалировала над численностью в середине (табл. 1). Причем во всех случаях площадь мицелия Trichoderma с краю превышала площадь мицелия в середине в несколько раз и на один порядок. В остальных образцах (C, B2, Е16) колонии грибов не прорастали. После образования плодовых тел было установлено, что грибы представлены также родами Aspergillus и Penicillium. Число колоний Aspergillus также было выше с края почвы у бордюра: в Е1-30 колоний, в Е1-2-1 колония. В Д1 и Д1-2 число колоний Penicillium также превалировало с края почвенного горизонта: 8 к 2 колониям соответственно.
В отношении водорослей наблюдались следующие особенности. Во всех пробах с края почвенного горизонта происходило более интенсивное и ускоренное развитие различных видов водорослей. Это наблюдалось, как в отношении стекол обрастания, так и воды с почвенной пробой (табл. 3). Пробы с края почвы всегда отличались более ярким цветом не только стекол обрастания, но самих пробирок, которые окрашивались уже во второй, третий день экспозиции. В первую неделю экспозиции в крайних пробах почвы было выше проективное покрытие и численность водорослей по сравнению с пробами из середины почвы. Вторую неделю разнообразие водорослей из середины почвы снижалось, тогда как в крайних участках почвы, наоборот увеличивалось (табл. 3).

Вместе с тем численность водорослей из крайних участков почвы также была выше. К этому времени с края доминировали, как правило, сине-зеленые, зеленые, эвгленовые водоросли и трихомные эукариоты. Тогда, как в середине почвы доминировали диатомовые. В донных отложениях были выявлены следующие закономерности (табл. 4).

У ила, граничащего с вертикальными искусственными субстратами, доминировали колониальные зеленые водоросли. В континуальном профиле илов в отдалении от искусственных барьеров наоборот доминировали трихомные формы водорослей, как в искусственных условиях среды (аквариум), так и в природных условиях (озера). Исключением являлась проба из аквариума с растениями, где трихомные формы водорослей наоборот доминировали с края ила. Данное явление может являться вытеснением высшими растениями антагонистов водорослей в краевые участки отложений. Обратная картина наблюдалась в песчаных отложениях озера Смолино, где трихомные формы, наоборот доминировали у края. Данное явление может объясняться спецификой трихомных форм специализирующихся на связывании более крупных частиц [10]. Размеры частиц песка сопоставимы с почвенными агрегатами, где также доминировали трихомные формы с краев орга- 
Таблица 3. Состав водорослей с краевых и континуальных участков различных почв через 2 недели экспозиции (клеток/в поле зрения).

\begin{tabular}{|c|c|c|}
\hline \multirow{3}{*}{ Группа организмов } & Край & Середина \\
\hline & B2 & B2-2 \\
\hline & \multicolumn{2}{|l|}{ Стекло } \\
\hline Chlorophyta (колонии) & 30 & 40 \\
\hline Diatomeae & 3 & - \\
\hline Euglenoidea & 1 & - \\
\hline \multirow[t]{2}{*}{ Zygnematales (трихомные) } & 4 & 1 \\
\hline & \multicolumn{2}{|l|}{ Почва } \\
\hline Chlorophyta (колонии) & 40 & 30 \\
\hline Diatomeae & - & 4 \\
\hline Zygnematales (трихомные) & - & 1 \\
\hline \multirow[t]{3}{*}{ Итого: } & 78 & 76 \\
\hline & A1 & A1-2 \\
\hline & \multicolumn{2}{|l|}{ Стекло } \\
\hline Cyanophyta (трихомные) & 2 & - \\
\hline Chlorophyta (колонии) & 4 & 15 \\
\hline Chlorophyta (одноклеточные) & 10 & - \\
\hline Zygnematales (трихомные) & 5 & 3 \\
\hline Ulotrichales (трихомные) & 4 & - \\
\hline \multirow[t]{3}{*}{ Итого: } & 25 & 24 \\
\hline & E1 & E1-2 \\
\hline & \multicolumn{2}{|l|}{ Стекло } \\
\hline Cyanophyta & 9 & - \\
\hline Chlorophyta & 16 & 7 \\
\hline Euglenoidea & 1 & - \\
\hline \multirow[t]{2}{*}{ Zygnematales (трихомные) } & 3 & - \\
\hline & \multicolumn{2}{|l|}{ Почва } \\
\hline Cyanophyta & 22 & 20 \\
\hline Chlorophyta & 6 & - \\
\hline Diatomeae & 6 & 20 \\
\hline Euglenoidea & 5 & - \\
\hline Zygnematales (трихомные) & 3 & - \\
\hline \multirow[t]{3}{*}{ Итого: } & 71 & 27 \\
\hline & Д1 & Д1-2 \\
\hline & \multicolumn{2}{|c|}{ Стекло } \\
\hline Cyanophyta & 63 & 2 \\
\hline Chlorophyta & 2 & 2 \\
\hline Euglenoidea & 4 & - \\
\hline Zygnematales (трихомные) & 3 & - \\
\hline Итого: & 72 & 4 \\
\hline
\end{tabular}

номинеральных комплексов. В континуальном профиле илов трихомные водоросли связывают органоминеральный комплекс в горизонтальном направлении, формируя таким образом его устойчивость. Установлено, что наиболее активно трихомы различных водорослей связывают частицы размером 50-100 мкм и более, для которых перестают действовать сила адгезии [10]. Также в отдалении от края в илах доминировали схожие по форме тела животные - так называемая инфа- уна, представленная нематодами и малощетинковыми червями (табл. 4). Ракообразные и простейшие, наоборот доминировали в порах у края. Здесь следует отметить, что у края доминировали более крупные формы простейших, представленных инфузориями.

Следующим этапом исследований являлось выявление границ переходной зоны органоминеральных комплексов, обеспечивающих развитие экотона. Ранее 
Таблица 4. Состав фауны и флоры различных участков органоминерального комплекса донных отложений в искусственных и естественных условиях: водоросли —\%, простейшие - экз./мкл, животные (ракообразные, нематоды) - экз./см³.

\begin{tabular}{|c|c|c|}
\hline Группа организмов & Край & Середина \\
\hline & \multicolumn{2}{|c|}{ Органический ил из аквариума с водорослями } \\
\hline Колониальные вдрсл. & 10 & - \\
\hline Трихомные вдрсл. & - & 30 \\
\hline \multirow[t]{2}{*}{ Простейшие } & 13 & 2 \\
\hline & \multicolumn{2}{|c|}{ Органический ил из аквариума с растениями } \\
\hline Колониальные вдрсл. & 10 & 10 \\
\hline Трихомные вдрсл. & 20 & 10 \\
\hline \multirow[t]{2}{*}{ Простейшие } & 20 & 11 \\
\hline & \multicolumn{2}{|c|}{ Органический ил из аквариума с соленой водой } \\
\hline \multirow[t]{2}{*}{ Колониальные вдрсл. } & 40 & 10 \\
\hline & \multicolumn{2}{|c|}{ Банка с илом } \\
\hline Трихомные вдрсл. & 20 & 30 \\
\hline \multirow[t]{2}{*}{ Простейшие } & 15 & 9 \\
\hline & \multicolumn{2}{|c|}{ Банка с органическим илом } \\
\hline \multirow[t]{2}{*}{ Трихомные вдрсл. } & 20 & 40 \\
\hline & \multicolumn{2}{|c|}{ Банка с соленым илом } \\
\hline Трихомные вдрсл. & 0 & 30 \\
\hline \multirow[t]{2}{*}{ Простейшие } & 10 & 2 \\
\hline & \multicolumn{2}{|c|}{ Оз. Хомутинино } \\
\hline \multirow[t]{2}{*}{ Колониальные вдрсл. } & 40 & 10 \\
\hline & \multicolumn{2}{|c|}{ Оз. Подборное } \\
\hline Колониальные вдрсл. & 10 & 0 \\
\hline Трихомные вдрсл. & 0 & 20 \\
\hline Ракообразные & 12 & 2 \\
\hline Нематоды & - & 12 \\
\hline \multirow[t]{2}{*}{ Простейшие } & 38 & 4 \\
\hline & \multicolumn{2}{|c|}{ Оз. Копанцево } \\
\hline Колониальные вдрсл. & 10 & 0 \\
\hline Ракообразные & 10 & - \\
\hline Нематоды & 1 & 15 \\
\hline \multirow[t]{2}{*}{ Простейшие } & 8 & 3 \\
\hline & \multicolumn{2}{|c|}{ *Оз. Смолино 1} \\
\hline Трихомные вдрсл. & 20 & 0 \\
\hline \multirow[t]{2}{*}{ Колониальные вдрсл. } & 0 & 10 \\
\hline & \multicolumn{2}{|c|}{ *Оз. Смолино 2} \\
\hline Трихомные вдрсл. & 10 & 0 \\
\hline Колониальные вдрсл. & 10 & 0 \\
\hline
\end{tabular}

* — песчаные отложения.

нами было выявлено повышенное содержание нитратов, фосфатов с краев органоминеральных комплексов донных отложений и почв, что свидетельствовало об аэрофильном режиме данных участков и более окислительных условиях по отношению к континуальной части данных комплексов [2]. В градиенте отдаления от различных искусственных субстратов концентрация фосфатов снижалась (рис. 1). Причем для минеральной плиты ( $p=0.051)$ и дома ( $p=0.051)$ была выявлена статистически значимая связь, а для бордюра $(p=0.1)$ и бе- тона ( $p=0.081)$ тенденция к статистически значимой связи. Концентрация нитратов также незначительно снижалась, однако не статистически значимо, за исключением показателей близких к тенденции у бордюра $(p=0.117)$ и бетона $(p=0.179)$. В отдалении минеральной плиты и дома на 15 см было выявлено относительно резкое снижение концентрации нитритов (рис. 1). При этом концентрация аммония также снижалась, однако статистически значимых связей выявлено не было. Также наблюдалось резкое повышении $\mathrm{pH}$ на расстоя- 

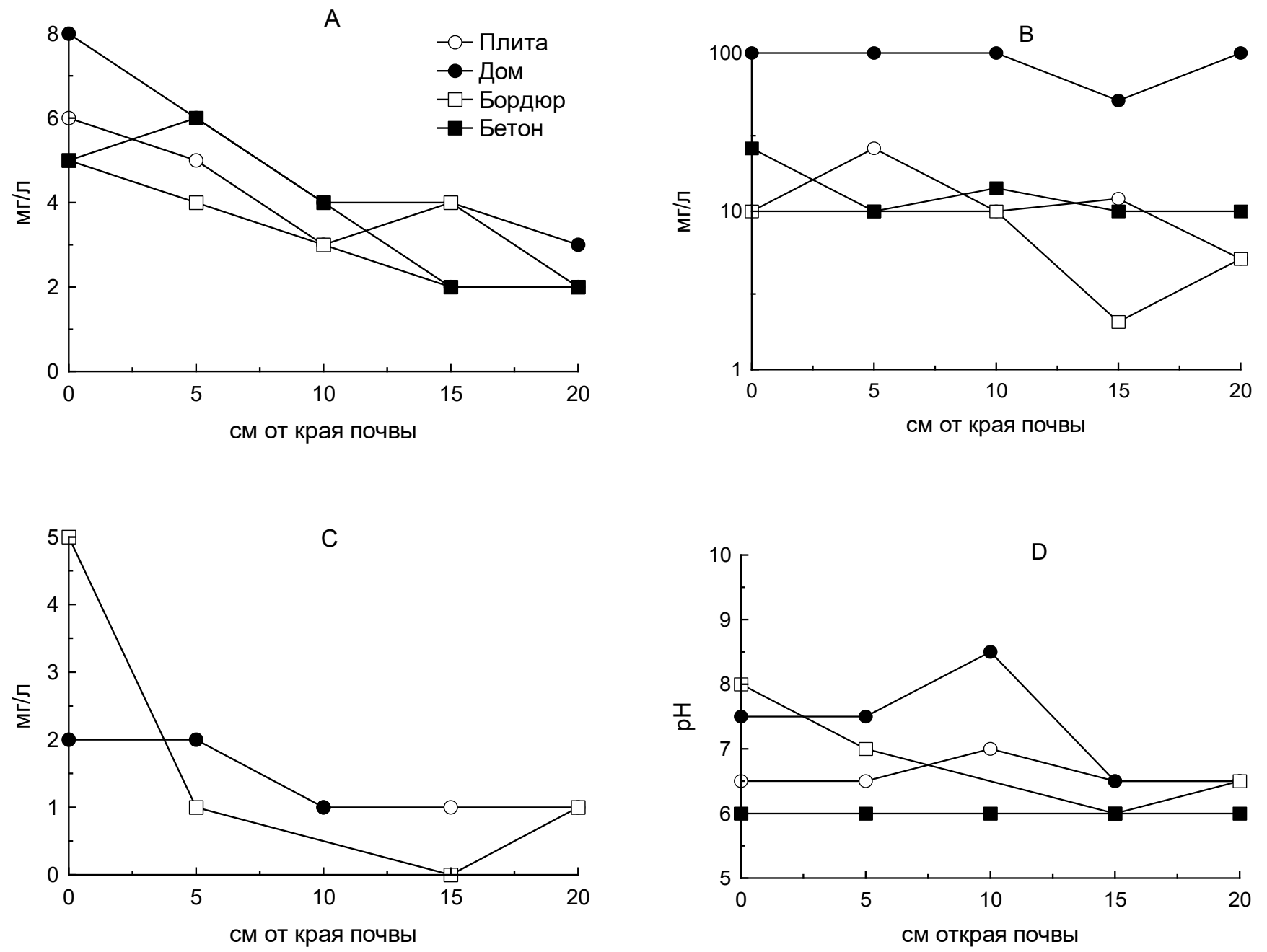

Рис. 1. Распределение химических показателей в горизонтальном профиле почвы при отдалении от различных искусственных субстратов: A — фосфаты, B - нитриты, С - аммоний, D - pH.
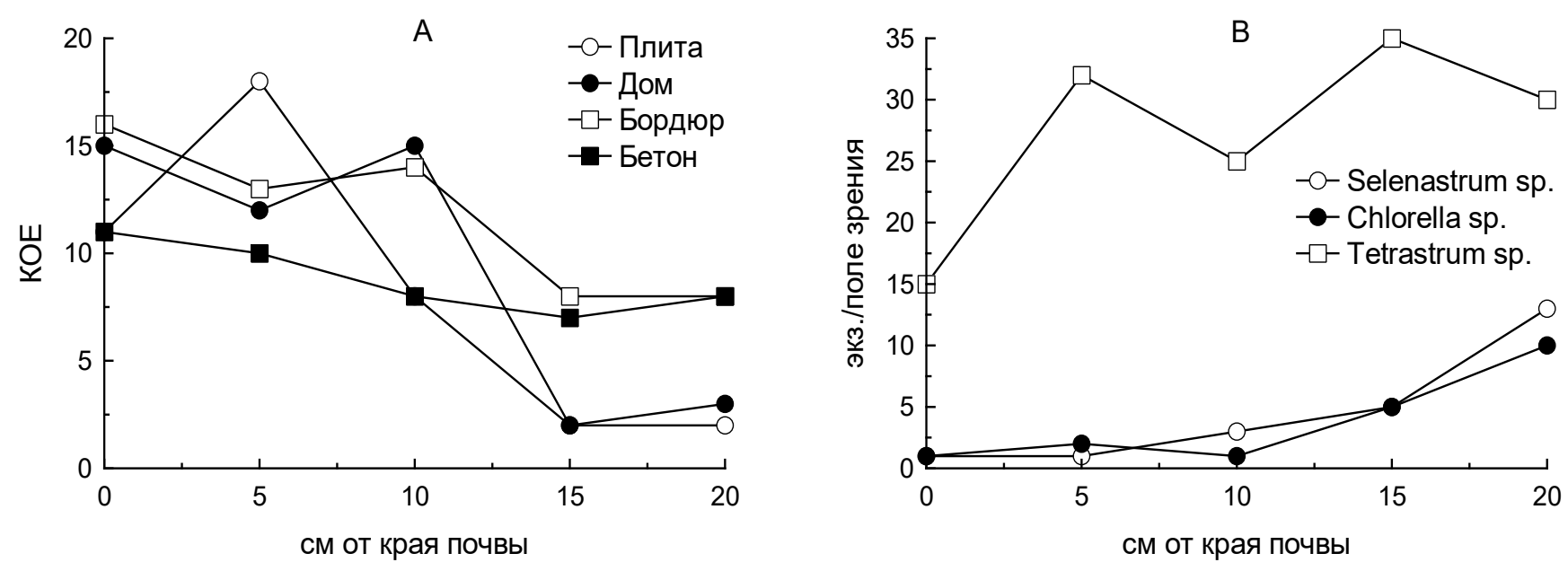

Рис. 2. Распределение KOE (А) и различных водорослей (В) в горизонтальном профиле почвы. 


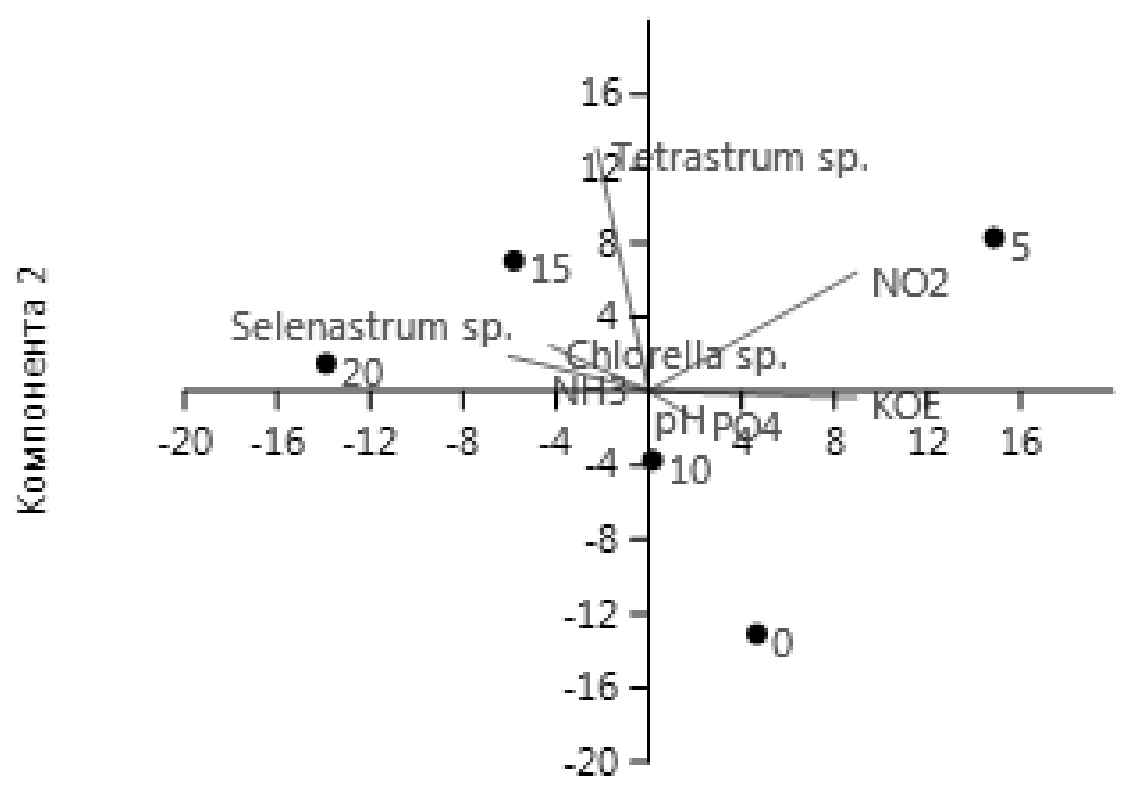

\section{Компонента 1}

Рис. 3. Распределение в многомерном пространстве главных компонент KOE, водорослей и химических показателей при отдалении почвы от искусственного субстрата, где цифрами обозначено расстояние в см от края почвенного профиля.

нии 10 см от края плиты и дома. То есть в 10-15 см наблюдался эффект геохимического барьера, что по всей видимости, обусловлено особенностями высыхания органоминерального комплекса и режима увлажнения ограниченного данной протяженностью [2].

Численность колоний бактерий при отдалении от различных искусственных субстратов снижалась (рис. 2). Причем, для плиты, бордюра и бетона была выявлена статистически значимая связь $(p=0.076)$. Численность трех различных форм водорослей (Selenastrum sp., Chlorella sp., Tetrastrum sp.) в горизонтальном профиле почвы при отдалении от плиты снижалась незначительно (рис. 2). Однако, статистически значимой связи падения численности наблюдавшихся на всем горизонтальном профиле почвы водорослей при отдалении от искусственного субстрата выявлено не было. Следует отметить, что культивирование различных участков почвы, наоборот показало наиболее быстрое и обильное развитие водорослей из профилей 0-5 см от края почвы. Это может свидетельствовать о накоплении на этих участках именно спор водорослей, находящихся в пуле и дающих вспышку численности при благоприятных (увлажненных) условиях.

В многомерном пространстве главных компонент три группы водорослей распределены в более щелочной среде на более отдаленных участках - 15-20 см от края почвы (рис. 3). Бактерии наоборот были приближены к краевым участкам почвы (0-5 см) и повышенным концентрациям нитритов и фосфатов. При этом общий тренд распределения химических элементов демонстрировал увеличение окисленных азотсодержащих соединений к краю почвы. Водоросль Selenastrum $s p$. характеризовалась статистически значимой зависимостью с бактериями и фосфатами $(p=0.05)$, также была выявлена тенденция к статистической значимости между Chlorella sp. и фосфатами $(\mathrm{p}=0.15)$.

\section{Зак^ючение}

Более высокая численность микроорганизмов, их более интенсивное развитие на краях почвенного горизонта обусловлена тем, что в полостях между почвой и искусственным субстратом накапливается большое количество спор, отдельных клеток и колоний бактерий, грибов и водорослей с различными экологическими стратегиями и высоким таксономическим разнообразием. Так, как условия на краях вертикальных разрезов почв более нестабильны доминирующее значение получают виды с r-стратегией. (Аналогичная картина наблюдается в донных отложениях). В континуальном слое почвы, в отдалении искусственных барьеров доминируют трихомные формы водорослей, которые способствуют связыванию почвенного профиля. В континуальных участках илов наблюдается повышенная 
концентрация инфауны - в виде нематод. В краевых поровых участках илов, граничащих с искусственными субстратами, наблюдается повышенная численность ракообразных, крупных простейших и других планктонных и перифитонных форм. В период высыхания органоминерального почвенного комплекса в полость между искусственным субстратом и почвой посредством ветра сдуваются и накапливаются споры и отдельные клетки микроорганизмов. Аналогичный процесс может происходить при вымывании пула микроорганизмов в щели между почвой и искусственным субстратом. В отношении бактериальной и микологической обсемененности краевых участков почвы следует уделить внимание санитарно-гигиеническим аспектам.
Микроэлементный состав, преобладание фосфатов, нитратов способствует более интенсивному развитию биоты на краях почвенных профилей. Таким образом, краевые участки почвы отличаются повышенной продукцией микробиоты по сравнению с континуальными, тогда как континуальные характеризуются более сложной структурой и замедленным функционированием.

Экотонный эффект наблюдается в пределах 5-10 см от края почвы граничащей с искусственными барьерами. На данных участках происходит повышение концентрации окисленных соединений, увеличение численности бактерий.

\section{ЛИТЕРАТУРА}

1. Воробьев А.А., Кривошеин Ю.С., Широбоков В.П. Медицинская и санитарная микробиология: учебное пособие для студентов высш. мед. учебн. заведений. М: Издательский центр «Академия», 2003. 464 с.

2. Заварзин Г.А. Лекции по природоведческой микробиологии. М.: Наука, 2003.348 с.

3. Зенова Г.М., Кураков А.В. Методы определения структуры комплексов почвенных актиномицетов и грибов. М.: Изд-во МГУ, 1988. 54 с.

4. Зенова Г.М., Штина Э.А. Почвенные водоросли: учебное пособие. М.: Изд-во МГУ, 1990. 80 с.

5. К Кашкин П.Н., Елинков К.П. Безбородов А.М., Цыганов В.А., Антибиотики. Л. Медицина. — Ленинградское отделение, 1970. 375 с.

6. Корляков К.А., Нохрин Д.Ю., Арсентьева Н.Ю. Влияние неровностей рельефа стекол на формирование сообществ и монокультур обрастаний // Биология внутренних вод. 2015. № 1. С. 96-104.

7. Корляков К.А. Предварительные результаты исследования экотонов урбаноземов методом культивирования пула биоты из вертикальных профилей // Актуальные вопросы современного естествознания Южного Урала: материалы III Всерос. науч.-практ. конф., 21 декабря 2018. Челябинск: Издво Челяб. гос. ун-та, 2018. С. 35-40.

8. Кузнецов С.И., Дубинина Г.А. Методы изучения водных микроорганизмов. М.: Наука, 1989. 285 с.

9. Нетрусов А.И., Котова И.Б. Микробиология. М: Издательский центр «Академия», 2006. 352 с.

10. Garcia-Pichel F., Wojciechowski M.F. The evolution of a capacity to build supra-cellular ropes enabled filamentous cyanobacteria to colonize highly erodible substrates // Plos ONE. 2009. 4(11). P. 1-6.

11. Sokal R.R., Rohlf F.J. Biometry: the principles and practice of statistics in biological research. N.-Y.: Freeman \& Co, 1995. 850 p.

12. Yoshioka K. KyPlot — a user-oriented tool for statistical data analysis and visualization // Computational Statistics. 2002. V. 17. № 3. P. $425-437$.

(с Корляков Константин Александрович ( korfish@mail.ru ). 